${ }^{1}$ National University of Pharmacy

${ }^{2}$ Tajik National University

\title{
The study of biologically active substances of the extract obtained from peach leaves of the tajik variety
}

Aim. To study the qualitative composition and the content of biologically active substances (BAS) in the extract obtained from peach leaves grown in Tajikistan, its numerical parameters and choose the parameters for standardization of the extract.

Materials and methods. The object of the study was a soft extract obtained from peach leaves of the "Salvey" variety. For standardization the numerical parameters were determined in 5 batches of the extract. A dry residue, the content of heavy metals and microbiological purity were studied in the extract by the methods of the State Pharmacopoeia of Ukraine (SPhU). The qualitative reaction and thin-layer chromatography (TLC) were proposed for identification of the extract. The content of the amount of phenolic compounds, flavonoids and hydroxycinnamic acids was determined using spectrophotometry calculated with reference to gallic acid, rutin and chlorogenic acid, respectively. The content of polysaccharides was determined gravimetrically, and the content of organic acids by titrimetry according to the SPhU monograph "Rosehips".

Results and discussion. A dry residue of the extract was $78.27 \pm 0.12 \%$. The content of heavy metals did not exceed $0.001 \%$. According to the results of microbiological purity determination the extract met the SPhU requirements. According to the results of the reaction with the solution of Ferrum (III) chloride the presence of phenolic substances was confirmed. During the TLC analysis several spots were observed, one of which appeared at the level of the standard sample of chlorogenic acid. The quantitative content (\%) of the following substances was determined in the extract: polysaccharides $-14.74 \pm 0.09$, organic acids $-3.71 \pm 0.09$, phenolic compounds $-12.85 \pm 0.39$, flavonoids $-4.71 \pm 0.09$, hydroxycinnamic acids $-8.41 \pm 0.07$.

Conclusions. The analysis of BAS of a soft extract from peach leaves has been carried out. The parameters of its standardization have been selected.

Key words: peach; leaves; extract; analysis; standardization

Г. Ф. Наврузова, В. С. Кисличенко, Л.В.Ленчик

\section{Дослідження біологічно активних речовин екстракту, отриманого з листя} персика Таджицьких сортів

Мета роботи - вивчення якісного складу та вмісту біологічно активних речовин (БАР) в екстракті, отриманому з листя персика Таджицьких сортів, його числових показників і вибір параметрів стандартизації екстракту.

Матеріали і методи. Об'єктом дослідження був густий екстракт, одержаний з листя персика сорту «Сальвей». Для стандартизації визначали числові показники у 5 серіях екстракту. В екстракті було вивчено за ДФУ сухий залишок, вміст важких металів та мікробіологічну чистоту. Для ідентифікації екстракту запропоновано якісну реакцію та тонкошарову хроматографію (ТШX). Кількісне визначення суми фенольних сполук, фрлавоноїдів та гідроксикоричних кислот проводили спектрофотометрично у перерахунку на галову кислоту, рутин та хлорогенову кислоту відповідно. Вміст полісахаридів визначали гравіметрично; органічних кислот - титриметрично за монографією ДФУ «Плоди шипшини».

Результати та їх обговорення. Сухий залишок екстракту становить 78,27 $\pm 0,12$ \%. Вміст важких металів не перевищував 0,001 \%. За результатами визначення мікробіологічної чистоти екстракт відповідав вимогам ДФУ. Реакцією з розчином феруму (III) хлориду підтверджено наявність фенольних речовин. При проведенні хроматографічного аналізу відмічали декілька плям, одна з яких знаходилась на рівні стандартного зразка хлорогенової кислоти. В екстракті визначено кількісний вміст (\%): 14,74 \pm 0,09 полісахаридів, 3,71 \pm 0,09 органічних

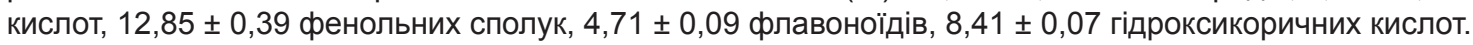

Висновки. Проведено аналіз БАР густого екстракту, отриманого з листя персика та обрані параметри його стандартизації.

Ключові слова: листя; персик; екстракт; аналіз; стандартизація

Г. Ф. Наврузова, В. С. Кисличенко, Л.В.Ленчик

\section{Исследование биологически активных веществ экстракта, полученного из листьев персика Таджикских сортов}

Цель работы - изучение качественного состава и содержания биологически активных веществ (БАВ) в экстракте, полученном из листьев персика Таджикских сортов, его числовых показателей и выбор параметров стандартизации экстракта. 
Материалы и методы. Объектом исследования был густой экстракт, полученный из листьев персика сорта «Сальвей». Для стандартизации определяли числовые показатели в 5 сериях экстракта. В экстракте были определены по ГФУ сухой остаток, содержание тяжелых металлов и микробиологическая чистота. Для идентифрикации экстракта предложена качественная реакция и тонкослойная хроматография (ТСX). Количественное определение суммы фенольных соединений, фрлавоноидов и гидроксикоричных кислот проводили спектрофотометрически в пересчете на галловую кислоту, рутин и хлорогеновую кислоту, соответственно. Содержание полисахаридов определяли гравиметрически; органических кислот - титриметрически по монографии ГФУ «Плоды шиповника».

Результаты и их обсуждение. Сухой остаток экстракта составляет 78,27 \pm 0,12 \%. Содержание тяжелых металлов не превышало 0,001 \%. По результатам определения микробиологической чистоты экстракт отвечал требованиям ГФУ. Реакцией с раствором железа (III) хлорида подтверждено наличие фенольных веществ. При проведении ТСХ отмечали несколько пятен, одно из которых находилось на уровне стандартного образца хлорогеновой кислоты. В экстракте определено количественное содержание (\%): 14,74 \pm 0,09 полисахаридов,

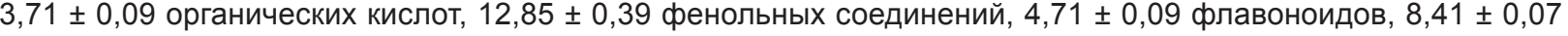
гидроксикоричных кислот.

Выводы. Проведен анализ БАВ густого экстракта, полученного из листьев персика. Выбраны параметры его стандартизации.

Ключевые слова: листья; персик; экстракт; анализ; стандартизация

Peaches (Persica vulgaris Mill), family Rosaceae are widely cultivated throughout the world. China, Italy and the United States are the leading countries in the production of peach fruits [1]. In the Republic of Tajikistan this crop is also popular and is grown in many areas, providing a sufficient raw material base for production of phytomedicines. The Republic of Tajikistan has specific climatic conditions, and late flowering and winter-resistant varieties are common.

The presence of organic acids, coumarins, flavonoids, condensed tannins, hydroxycinnamic acids, saponins in peach leaves harvested in Tajikistan was confirmed with qualitative reactions and the generally accepted research methods of paper and thin layer chromatography $[2,3,4]$.

The extract was obtained by maceration from peach leaves. The qualitative composition of the extract was studied, and the content of phenolic compounds was determined by the method of high-performance liquid chromatography (HPLC). According to the results of the study the presence of eight substances of phenolic nature, namely 2 derivatives of hydroxycinnamic acids and 6 flavonoids, was determined. Chlorogenic acid was present in the greatest amount $-29.96 \mathrm{mg} / 100 \mathrm{ml}$. Among flavonoids the largest quantity was found for hyperoside $3.72 \mathrm{mg} / 100 \mathrm{ml}$, and rutin contained in the amount of $1.80 \mathrm{mg} / 100 \mathrm{ml}$. Quercetin, luteolin, luteolin-7-O-glycoside, apigenin-7-O-glycoside were present in the extract in a trace amount [3].

The pharmacological studies were conducted under the supervision of professor H. V. Zaychenko. It was found on the model of carrageenan edema of the rat's foot that the extract exhibited the anti-inflammatory activity in the dose of $50 \mathrm{mg} / \mathrm{kg}$. The immunotropic activity of the extract was studied in vitro. It was determined in the tests that the peach extract had a moderately expressed stimulating effect in relation to the factors of the innate and acquired immunity. The immunostimulatory activity of the peach leaf extract was the most marked in the low concentration of $0.4 \mathrm{mg} / \mathrm{ml}$ than in the high one $-2 \mathrm{mg} / \mathrm{ml}[2,4]$.
The aim of the research was to study the qualitative composition and the content of BAS in the extract obtained from peach leaves of the Tajik variety, its numerical parameters and to choose the parameters for standardization of the extract.

\section{Materials and methods}

The object of the study was a soft extract obtained from peach leaves of the "Salvey" variety in August of 2014 after fruits harvesting.

For standardization the numerical parameters were determined in 5 batches of the extract obtained in laboratory conditions.

A dry residue was determined according to the method (2.8.16) of the State Pharmacopoeia of Ukraine (SPhU). For this purpose $2.00 \mathrm{~g}$ of the extract was placed in a flat-bottomed cup with the diameter of approximately $50 \mathrm{~mm}$ and dried in a drying cabinet at a temperature of $100-105^{\circ} \mathrm{C}$ for $3 \mathrm{~h}$, cooled in a desiccator over phosphorus $(V)$ oxide and weighed. The result was expressed in weight percentage [5]. The content of heavy metals and microbiological purity in the extract were studied by the SPhU methods.

The qualitative reaction and TLC were chosen for identification. According to the European Pharmacopoeia recommendations only the TLC method should be used for identification of herbal drugs [6]. The principles of TLC and the method of its application in the pharmaceutical analysis are described in the SPhU [5]. Since it is effective and easy to perform, and the equipment required is inexpensive, this method is frequently used for assessing the quality of the medicinal plant raw material and phytomedicines $[5,6,7]$.

For conducting the TLC analysis $0.2 \mathrm{~g}$ of the soft extract was dissolved in the minimum amount of hot water and applied as a strip of $0.5 \mathrm{~cm}$ in width on the starting line of the "Sorbfil" plate. Nearby, $0.005 \mathrm{ml}$ of $0.1 \%$ solution of the standard sample of chlorogenic acid was applied and chromatographed in the solvent system of toluene: ethyl acetate: anhydrous formic acid: water $(2: 20: 2: 1)$. When the solvent front reached the 
finish line, the chromatogram was removed from the chamber, dried in a vent hood and viewed in UV light at the wavelength of $360 \mathrm{~nm}$.

The quantitative determination of the amount of phenolic compounds was carried out using spectrophotometry calculated with reference to gallic acid [8]. The content of polysaccharides was determined gravimetrically [5]. The content of organic acids was determined by tit rimetry according to the SPhU monograph "Rosehips". The content of hydroxycinnamic acids calculated with reference to chlorogenic acid was carried out using spectrophotometry, and the content of flavonoids was calculated with reference to rutin [8].

\section{Results and discussion}

The extract was a viscous, thick mass of a browngreenish color with a bitter taste and a weak specific odor. A dry residue was $78.27 \pm 0.12 \%$. Heavy metals were within the error of the device and did not exceed $0.001 \%$.

According to the results of microbiological purity determination the absence of bacteria of the genus Escherichia coli, Salmonella, Pseudomonas aeruginosa and
Staphylococcus aureus was confirmed other bacteria were not more than 500 in the amount, while yeast and mold fungi were not more than 100 .

When few drops of iron (III) chloride was added to $1 \mathrm{ml}$ of aqueous solution (1:10) of a soft extract, a dark green color was observed, which was indicative of the presence of phenolic compounds [9].

Several spots were observed in the TLC analysis, one of which appeared at the level of the standard sample of chlorogenic acid and had a blue fluorescence, which when treated with ammonia solution became more intense.

The results of determination of the content of polysaccharides, organic acids, the amount of phenolic compounds calculated with reference to gallic acid, the amount of flavonoids calculated with reference to rutin, the amount of hydroxycinnamic acids calculated with reference to chlorogenic acid and the metrological characteristics of the average result of determination are given in Tab. 1 .

The content of polysaccharides and the amount of phenolic compounds (\%) were the highest in the extract 14.7 and 12.85 , respectively. The content of organic acids in the extract was the lowest. Phenolic compounds were

Table 1

The results of determination of the content of biologically active substances of the extract from peach leaves and their metrological characteristics

\begin{tabular}{|c|c|c|c|c|c|c|c|c|c|}
\hline $\mathrm{m}$ & $\mathrm{n}$ & $X_{i}$ & $X_{a v}$ & $S^{2}$ & $\mathrm{~S}_{\mathrm{av}}$ & $\mathrm{P}$ & $t(P, n)$ & Confidence interval & $\varepsilon, \%$ \\
\hline \multicolumn{10}{|c|}{ Polysaccharides } \\
\hline \multirow{5}{*}{5} & \multirow{5}{*}{4} & 14.65 & \multirow{5}{*}{14.74} & \multirow{5}{*}{0.005} & \multirow{5}{*}{0.030} & \multirow{5}{*}{0.95} & \multirow{5}{*}{2.78} & \multirow{5}{*}{$14.74 \pm 0.09$} & \multirow{5}{*}{0.57} \\
\hline & & 14.70 & & & & & & & \\
\hline & & 14.76 & & & & & & & \\
\hline & & 14.80 & & & & & & & \\
\hline & & 14.81 & & & & & & & \\
\hline \multicolumn{10}{|c|}{ Organic acids } \\
\hline \multirow{5}{*}{5} & & 3.61 & \multirow{5}{*}{3.71} & \multirow{5}{*}{0.006} & \multirow{5}{*}{0.034} & \multirow{5}{*}{0.95} & \multirow{5}{*}{2.78} & \multirow{5}{*}{$3.71 \pm 0.09$} & \multirow{5}{*}{2.51} \\
\hline & & 3.68 & & & & & & & \\
\hline & 4 & 3.72 & & & & & & & \\
\hline & & 3.75 & & & & & & & \\
\hline & & 3.81 & & & & & & & \\
\hline \multicolumn{10}{|c|}{ Phenolic compounds } \\
\hline \multirow{5}{*}{5} & & 12.84 & \multirow{5}{*}{12.85} & \multirow{5}{*}{0.1028} & \multirow{5}{*}{0.143} & \multirow{5}{*}{0.95} & \multirow{5}{*}{2.78} & \multirow{5}{*}{$12.85 \pm 0.39$} & \multirow{5}{*}{3.10} \\
\hline & & 12.58 & & & & & & & \\
\hline & 4 & 12.69 & & & & & & & \\
\hline & & 12.75 & & & & & & & \\
\hline & & 13.40 & & & & & & & \\
\hline \multicolumn{10}{|c|}{ Flavonoids } \\
\hline & & 1.61 & & & & & & & \\
\hline & & 1.68 & & & & & & & \\
\hline 5 & 4 & 1.72 & 4.71 & 0.0056 & 0.034 & 0.95 & 2.78 & $4.71 \pm 0.09$ & 1.98 \\
\hline & & 1.75 & & & & & & & \\
\hline & & 1.81 & & & & & & & \\
\hline & & & & & oxycinn & acids & & & \\
\hline & & 8.34 & & & & & & & \\
\hline & & 8.38 & & & & & & & \\
\hline 5 & 4 & 8.39 & 8.41 & 0.0028 & 0.024 & 0.95 & 2.78 & $8.41 \pm 0.07$ & 0.78 \\
\hline & & 8.45 & & & & & & & \\
\hline & & 8.47 & & & & & & & \\
\hline
\end{tabular}


The parameters of standardization of a soft extract from peach leaves

\begin{tabular}{|c|c|c|c|c|c|c|c|c|c|}
\hline \multirow{2}{*}{ 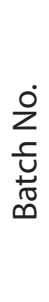 } & \multirow[b]{2}{*}{ Description } & \multicolumn{2}{|c|}{ Identification } & \multirow{2}{*}{ 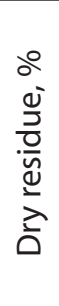 } & \multirow{2}{*}{ 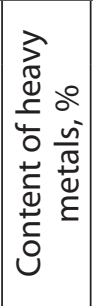 } & \multirow[b]{2}{*}{$\begin{array}{l}\text { Microbiological } \\
\text { purity, } \%\end{array}$} & \multirow{2}{*}{ 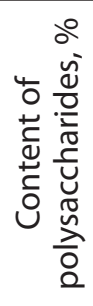 } & \multirow{2}{*}{ 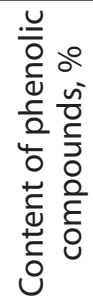 } & \multirow{2}{*}{ 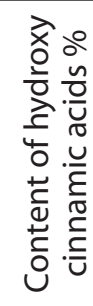 } \\
\hline & & $\begin{array}{l}\text { Qualitative } \\
\text { reactions }\end{array}$ & Chromatography & & & & & & \\
\hline 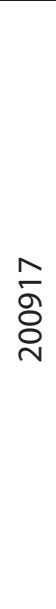 & $\begin{array}{c}\text { A viscous, } \\
\text { thick mass } \\
\text { of a brown- } \\
\text { greenish color, } \\
\text { bitter taste, } \\
\text { with a weak } \\
\text { specific odor }\end{array}$ & $\begin{array}{l}\text { With iron (III) } \\
\text { chloride - a } \\
\text { dark green } \\
\text { color (phenolic } \\
\text { compounds) }\end{array}$ & $\begin{array}{l}\text { The solvent system - } \\
\text { toluene: ethyl acetate: } \\
\text { anhydrous formic acid: } \\
\text { water (2: 20: } 2: 1) \text {. } \\
\text { "Sorbfil" plates. } \\
\text { Several spots appear, } \\
\text { one of which is at the } \\
\text { level of the standard } \\
\text { sample of chlorogenic } \\
\text { acid; it has a blue } \\
\text { fluorescence in UV } \\
\text { light at the wavelength } \\
\text { of } 365 \mathrm{~nm} \text {, when } \\
\text { treated with ammonia } \\
\text { solution it becomes } \\
\text { more intense }\end{array}$ & 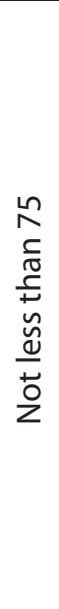 & 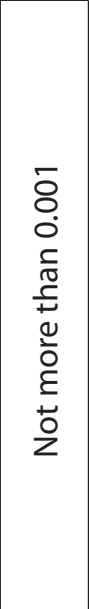 & $\begin{array}{l}\text { Not more than } 500 \\
\text { bacteria and } 100 \\
\text { yeast and mold } \\
\text { fungi (in total), } \\
\text { the absence of } \\
\text { bacteria of the } \\
\text { genus Escherichia } \\
\text { coli, Salmonella, } \\
\text { Pseudomonas } \\
\text { aeruginosa and } \\
\text { Staphylococcus } \\
\text { aureus }\end{array}$ & 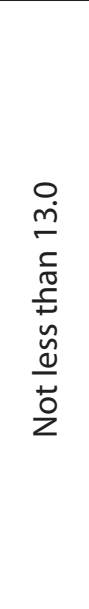 & 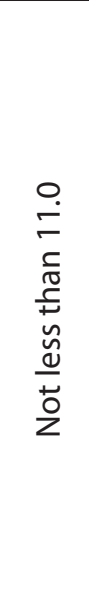 & 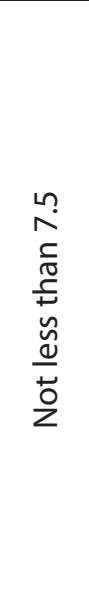 \\
\hline
\end{tabular}

represented by hydroxycinnamic acids and flavonoids. Moreover, the content of hydroxycinnamic acids exceeded the content of flavonoids almost in 2 times.

The pharmacological activity determined for the peach extract is related to phenolic compounds, namely hydroxycinnamic acids, and polysaccharides. Therefore, in order to standardize the extract obtained a qualitative reaction for determination of phenolic compounds and TLC, as well as for determination of the content of phenolic compounds, hydroxycholic acids and polysaccharides was proposed to select in "Identification" section. The parameters of standardization of a soft extract from peach leaves are given in Tab. 2.

\section{CONCLUSIONS}

1. The analysis of a soft extract obtained from peach leaves of the Tajik varieties has been carried out.

2 . The content of BAS and the numerical parameters of the extract have been determined.

3 . As the standardization parameters of the extract the reaction for determination of the presence of phenolic compounds and TLC, as well as the content of the amount of hydroxycinnamic acids, the amount of phenolic compounds and polysaccharides has been proposed to select in "Identification" section.

Conflict of Interests: authors have no conflict of interests to declare.

\section{REFERENCES}

1. FAO Statistical Pocketbook 2015. - Rome : Food and Agriculture Organization of the United Nations, 2015. - Available at : http:// faostat3.fao.org/

2. Фитохимическое и фармакологическое изучение листьев Persica vulgaris, заготовленных в Таджикистане / Л. В. Ленчик, Г. Ф. Наврузова, В. С. Кисличенко и др. // Республиканский научный журн. "Vestnik". - № 3 (68), Tом IV. - Шимкент : Серпилис, 2014. C. 126-132.

3. Study of phenolic compounds of peach leaves extract / L. Lenchyk, G. Navruzova, V. Kyslychenko, N. Saidov // Am. J. of Sci. and Technol. - 2015. - Vol. 2, Issue 20. - P. 795-799.

4. Study of Persica vulgaris leaves as prospective source of new phytomedicines / V. S. Kyslychenko, L. V. Lenchyk, G. F. Navruzova et al. // The 15 International Congress of the International Society for Ethnopharmacology, 05-08 of May 2015. - Petra, Jordan, 2015. - 114 p.

5. Державна фармакопея України / Державне підприємство «Український науковий фармакопейний центр якості лікарських засобів». - 2-е вид. - Х. : Український науковий фармакопейний центр якості лікарських засобів, 2014. - 732 с.

6. European Pharmacopoeia, 4-th ed. - Council of Europe, Strasburg. - 2002. - 2416 p.

7. Quality control methods for medicinal plant materials. - World Health Organization. - Geneva, 1998. - 123 p.

8. Стандартизація збору для лікування інфекційних захворювань легень і туберкульозу / Д. В. Упир, А. В. Мартинов, В. С. Кисличенко, Н. І. Ільїнська // Вісник фармації. - 2013.- № 2 (74). - С. 38-40.

9. Практикум по фармакогнозии : учеб. пособие для студ. вузов / В. Н. Ковалев, Н. В. Попова, В. С. Кисличенко и др. ; под. общ. ред. В. Н. Ковалева. - Х. : НФаУ; Золотые страницы, 2003. - 512 с. 


\section{REFERENCES}

1. FAO Statistical Pocketbook 2015. (2015). Rome: Food and Agriculture Organization of the United Nations. Available at: http://faostat3.fao.org/

2. Lenchik, L. V., Navruzova, G. F., Kislichenko, V. S., Sharipov, H. Sh., Zaichenko, A. V. (2014). Respublikanskii nauchnyi zhurnal "Vestnik", 3 (68), 126-132.

3. Lenchyk, L., Navruzova, G., Kyslychenko, V., Saidov, N. (2015). Study of phenolic compounds of peach leaves extract. American Journal of science and Technologies, 2 (20), 795-799.

4. Kyslychenko, V., Lenchyk, L., Navruzova, G., Sharifov, Kh., Zaychenko, G. (2015). Study of Persica vulgaris leaves as prospective source of new phytomedicines. The 15 international Congress of the international society for Ethnopharmacology, 05-08 of May 2015. Petra, 114.

5. Derzhavna Farmakopeia Ukrainy. (2 $2^{\text {nd }}$ ed.). (2015). Kharkiv: Ukrainskyi naukovyi farmakopeinyi tsentr yakosti likarskykh zasobiv, 723.

6. European Pharmacopoeia, 4th ed. (2002). Council of Europe. Strasburg, 2416.

7. Quality control methods for medicinal plant materials. (1998). World Health Organization. Geneva, 123.

8. Upyr, D. V., Martynov, A. V., Kyslychenko, V. S., Ilinska, N. I. (2013). Vìsnik farmacï, 2 (74), 38-40.

9. Kovalev, V. N., Popova, N. V., Kislichenko, V. S. (2003). Praktikum po farmakognozii. Kharkiv: NUPh, Zolotye stranitcy, 512.

\section{Information about authors:}

Navruzova G. F., teaching assistant of the Pharmacy Department, Tajik National University

Kyslychenko V. S., Doctor of Pharmacy (Dr. habil.), professor, head of the Chemistry of Natural Compounds Department, National University of Pharmacy.

E-mail: cnc@nuph.edu.ua

Lenchyk L. V., Candidate of Pharmacy (Ph. D.), associate professor of the Chemistry of Natural Compounds Department, National University of Pharmacy.

E-mail: larysa.lenchyk@gmail.com

Відомості про авторів:

Наврузова Г. Ф., асистент кафедри фармації, Таджицький національний університет

Кисличенко В. С., д-р фарм. наук, професор, завідувач кафедри хімії природних сполук, Національний фармацевтичний університет. Е-таil: сnс@пирһ.еdu.uа

Ленчик Л. В., канд. фарм. наук, доцент кафедри хімії природних сполук, Національний фармацевтичний університет. E-mail: larysa.lenchyk@gmail.com

Сведения об авторах:

Наврузова Г. Ф., ассистент кафедры фармации, Таджикский национальный университет

Кисличенко В. С., д-р фарм. наук, профессор, заведующая кафедрой химии природных соединений, Национальный фармацевтический университет.

E-mail: cnc@nuph.edu.ua;

Ленчик Л. В., канд. фарм. наук, доцент кафедры химии природных соединений, Национальный фармацевтический университет.

E-mail: larysa.lenchyk@gmail.com 